ARTICLE

\title{
The formation mechanism for printed silver-contacts for silicon solar cells
}

Jeremy D. Fields ${ }^{1, \star, \dagger}$, Md. Imteyaz Ahmad ${ }^{2, \star, \dagger}$, Vanessa L. Pool ${ }^{2}$, Jiafan Yu ${ }^{3}$, Douglas G. Van Campen ${ }^{2}$, Philip A. Parilla ${ }^{1}$, Michael F. Toney ${ }^{2} \&$ Maikel F.A.M. van Hest $^{1}$

Screen-printing provides an economically attractive means for making $\mathrm{Ag}$ electrical contacts to Si solar cells, but the use of Ag substantiates a significant manufacturing cost, and the glass frit used in the paste to enable contact formation contains $\mathrm{Pb}$. To achieve optimal electrical performance and to develop pastes with alternative, abundant and non-toxic materials, a better understanding the contact formation process during firing is required. Here, we use in situ $\mathrm{X}$-ray diffraction during firing to reveal the reaction sequence. The findings suggest that between 500 and $650^{\circ} \mathrm{C} \mathrm{PbO}$ in the frit etches the $\mathrm{SiN}_{\mathrm{x}}$ antireflectivecoating on the solar cell, exposing the Si surface. Then, above $650^{\circ} \mathrm{C}, \mathrm{Ag}^{+}$dissolves into the molten glass frit - key for enabling deposition of metallic $\mathrm{Ag}$ on the emitter surface and precipitation of $\mathrm{Ag}$ nanocrystals within the glass. Ultimately, this work clarifies contact formation mechanisms and suggests approaches for development of inexpensive, nontoxic solar cell contacting pastes.

\footnotetext{
${ }^{1}$ National Renewable Energy Laboratory, 15013 Denver West Pkwy, Golden, Colorado 80401, USA. ${ }^{2}$ SLAC National Accelerator Laboratory, 2575 Sand Hill Road, Menlo Park, California 94025, USA. ${ }^{3}$ Department of Electrical Engineering, Stanford University, 350 Serra Mall, Stanford, California 94305 , USA. * These authors contributed equally to this work. † Present address: SolarWorld Americas, 25300 NW Evergreen Road, Hillsboro, Oregon 97124, USA (J.D.F.); Department of Ceramic Engineering Indian Institute of Technology (BHU), Varanasi 221005, India (M. I. A.). Correspondence and requests for materials should be addressed to M.F.T. (email: mftoney@slac.stanford.edu) or to F.A.M.v.H. (email: Maikel.van.Hest@nrel.gov).
} 
B y far the most commercially viable option for photovoltaic energy generation, crystalline silicon ( $\mathrm{c}-\mathrm{Si}$ ) continues to dominate the industry with over $90 \%$ market share. Optimally designed silver (Ag) front-contacts in the majority of c-Si solar cells utilize narrow grid lines (approximate width of $50 \mu \mathrm{m})$ to minimize shading loss and achieve high current, high fill factor, and hence, high photo-conversion efficiency. While screen-printing provides an economically attractive means for making these contacts, owing to suitability for high-volume manufacturing, the use of Ag adds significantly to the solar cell cost. Furthermore, despite more than three decades of use in photovoltaic manufacturing, the mechanism of contact formation during the firing of screen-printed contacts remains a subject of debate. Achieving optimal firing conditions to minimize contact resistance, and to develop new pastes with alternative materials (that is, earth-abundant and non-toxic), requires a detailed understanding of the contact formation process. In situ X-ray diffraction (XRD) data obtained during rapid-thermal processing (RTP) of Ag-paste materials reveal that there are multiple competing anti-reflective layer burn-through and $\mathrm{Si}$ oxidation reactions occurring with different temperature thresholds. The primary reactive species responsible for burn-through is leadoxide $(\mathrm{PbO})$, and these $\mathrm{PbO}$ driven redox reactions lead to liquid $\mathrm{Pb}$ formation and reversible $\mathrm{Ag}-\mathrm{Pb}$ alloying during firing. Our in situ experiments also elucidate factors affecting dissolution of $\mathrm{Ag}$ into the frit and subsequent nanocrystal precipitation - key for achieving low contact resistance.

Typically, screen-printing contacts onto the n-type emitter of a p-type c-Si solar cell employs a paste consisting of Ag particles, organic binders and metal-oxide glass frit. The frit, usually a $\mathrm{PbO}$-based borosilicate glass, promotes a series of reactions allowing electrical contact to the emitter after deposition of the silicon-nitride $\left(\mathrm{SiN}_{\mathrm{x}}\right)$ anti-reflective and passivation layer during contact firing. Although the frit has long been known to enable this process ${ }^{1}$, conflicting arguments bring into question the specific role of the frit to enable $\mathrm{SiN}_{\mathrm{x}}$ burn-through and the mechanism of Ag transport to the $\mathrm{c}$-Si surface. Hence, the actual electrical contact formation pathway remains scarcely understood - largely because previous investigations lacked in situ measurement capabilities with the temporal-resolution and operating temperature range necessary to observe these processes in real-time.

Reactions responsible for contact formation occur during rapid heating, with ramp-rates of $50-100{ }^{\circ} \mathrm{Cs}^{-1}$, at temperatures of $500-800^{\circ} \mathrm{C}$. In general, the $\mathrm{Ag}$-paste is well known to penetrate the $\mathrm{SiN}_{\mathrm{x}}$ layer during firing by oxidation, and the resulting silicon-oxide $\left(\mathrm{SiO}_{2}\right)$ reaction product becomes incorporated into the molten frit. However, the associated oxidation reaction remains in question, since this can occur in one of several ways. The two most frequently cited arguments suggest either that $\mathrm{SiN}_{\mathrm{x}}$ is oxidized by $\mathrm{PbO}$ in the frit by ${ }^{2-4}$ :

$$
2 \mathrm{PbO}+\mathrm{SiN}_{\mathrm{x}} \rightarrow 2 \mathrm{~Pb}+\mathrm{SiO}_{2}+\frac{\mathrm{x}}{2} \mathrm{~N}_{2}
$$

or, that $\mathrm{Ag}$, which can dissolve in frit as silver oxide $\left(\mathrm{Ag}_{2} \mathrm{O}\right)$ up to approximately $5 \mathrm{wt} . \%$ (refs 5,6 ), etches the $\mathrm{SiN}_{\mathrm{x}}$ by $^{7,8}$ :

$$
\mathrm{SiN}_{\mathrm{x}}+2 \mathrm{Ag}_{2} \mathrm{O} \rightarrow \mathrm{SiO}_{2}+4 \mathrm{Ag}+\frac{\mathrm{x}}{2} \mathrm{~N}_{2}
$$

The second case is perhaps less obvious, since $\mathrm{Ag}_{2} \mathrm{O}$ itself readily decomposes under thermal activation, and so may not seem an obvious reactant at contact firing temperatures. However, $\mathrm{Ag}_{2} \mathrm{O}$ becomes more stable when bound in certain glasses, and therefore, technically both reactions (1) and (2) are thermodynamically feasible. In situ results presented in this work reveal the dominant $\mathrm{SiN}_{\mathrm{x}}$ burn-through reaction.
After $\mathrm{SiN}_{\mathrm{x}}$ opening, $\mathrm{Ag}$ contacts the $\mathrm{Si}$ emitter. Electrical conduction in fired contacts relies largely on tunneling through a layer of re-solidified glass frit, which forms between the $\mathrm{c}-\mathrm{Si}$ surface and Ag bulk during firing. Distributed precipitation of Ag and $\mathrm{Pb}$ nanocrystals within the glass enables the tunneling ${ }^{9-11}$. Minimizing the glass intermediate layer thickness, inducing Ag sintering and promoting a controlled amount of Ag deposition on the $\mathrm{c}$-Si surface (without spike-shunting the junction), are said to impart low contact resistance ${ }^{12}$. Here, certain additional details remain in question. For instance, the means by which Ag deposits onto the emitter is not obvious. According to some authors the deposition of $\mathrm{Ag}$ on the emitter requires the Ag to first oxidize by:

$$
2 \mathrm{Ag}+\frac{1}{2} \mathrm{O}_{2} \rightarrow \mathrm{Ag}_{2} \mathrm{O}
$$

and then dissolve into the glass frit before a subsequent redox reaction between $\mathrm{Ag}_{2} \mathrm{O}$ and c-Si (refs 13,14):

$$
2 \mathrm{Ag}_{2} \mathrm{O}+\mathrm{Si} \rightarrow \mathrm{SiO}_{2}+4 \mathrm{Ag}
$$

Not all agree with the $\mathrm{Ag}_{2} \mathrm{O}$-based deposition model. Schubert (ref. 15) and Horteis ${ }^{16}$ argue that $\mathrm{Pb}$ formed in reaction 1 lowers the Ag-Si interaction temperature such that when the molten system phase separates upon cooling Ag deposits on the Si surface and within the glass layer. Sopori et al. ${ }^{17}$ agree with an Ag-Si alloy-assisted contact formation mechanism, and suggest involvement of other metal solvent species to further depress the melting temperature. In addition, the extent of $\mathrm{Pb}$ formation, argued to assist in $\mathrm{Ag}$ sintering, has been questioned. Thus, ambiguity persists regarding details of metal transport and precipitation, the extent of $\mathrm{Ag}-\mathrm{Pb}$ alloying, the extent of $\mathrm{Ag}-\mathrm{Pb}-\mathrm{Si}$ alloying if any occurs at all, and therefore the keys for achieving low contact resistance.

Here, direct observation of $\mathrm{SiN}$ etching by $\mathrm{PbO}$ and $\mathrm{Ag}_{2} \mathrm{O}$ during different stages of firing using in situ XRD reveals the burn-through reaction and contact formation sequence. Studies on Ag, frit, c-Si and $\mathrm{SiN}$ model systems show a strong dependence of $\mathrm{Pb}$ formation, and hence $\mathrm{Ag}-\mathrm{Pb}$ alloying, on oxygen $\left(\mathrm{O}_{2}\right)$ partial pressure during firing. In addition, Ag dissolution into the glass frit, and hence the resulting abundance of Ag precipitate formation, shows a strong $\mathrm{O}_{2}$-dependence. This investigation finds the $\mathrm{Ag}$ redox reactions only occur with sufficient $\mathrm{O}_{2}$ at temperatures higher than $650{ }^{\circ} \mathrm{C}$ - negating a role of $\mathrm{Ag}$ in opening of the antireflective-coating at lower temperatures. Our findings also explain increased $\mathrm{Pb}$ formation observed when firing in a $\mathrm{N}_{2}$ atmosphere compared with air. Understanding the temperature thresholds for each of these competing mechanisms accurately clarifies the nature of screen-printed, fast-fired contacts.

\section{Results}

Powder model system. Model systems containing Ag nanocrystals, $\mathrm{PbO}$-based frit, $\mathrm{SiN}_{\mathrm{x}}$ and $\mathrm{c}$ - $\mathrm{Si}$, in varying combinations, have been fired in an air or nitrogen $\left(\mathrm{N}_{2}\right)$ atmosphere and characterized using an in situ XRD/RTP apparatus ${ }^{18}$. Use of powder model systems enabled characteristic XRD data acquisition with short collection intervals $(<1 \mathrm{~s})$, with high signal-to-noise achievable due to high interface area between reactants of interest within the sampled volume. This allowed detection of varying reaction species abundance with high sensitivity during rapid heating and cooling with temperature profiles analogous to solar cell contact firing conditions. This provides a unique opportunity to observe the reaction sequence in real time; such detailed analysis is impossible to perform on an actual Ag contact on a solar cell during firing in a belt-furnace. Results at the end of this section show that the powder mixture model systems fired by RTP in the present study behave analogous to fast-fired contacts made by 
screen-printing with conventional Ag pastes. Sample preparation and measurement procedures are explained further in the Methods section.

$\mathrm{Pb}$ formation. XRD patterns measured during firing of a frit/ $\mathrm{SiN}_{\mathrm{x}}$ (1:1 molar ratio) mixture in air to $800^{\circ} \mathrm{C}$ (Fig. 1a) demonstrate the in situ measurement capability. The frit and amorphous-SiN $\mathrm{S}_{\mathrm{x}}$ generate only weak, broad diffraction, in the initial patterns. However, sharp crystalline- $\mathrm{Pb}$ peaks emerge after firing, as the system cools below $327^{\circ} \mathrm{C}$ (the melting temperature of $\mathrm{Pb}$ ), which substantiates evidence of reaction 1. Results from analogous measurements on $\mathrm{Ag} /$ frit/ $/ \mathrm{SiN}_{\mathrm{x}}$ mixtures (Fig. 1b), fired to 500 , 600,700 and $800^{\circ} \mathrm{C}$, in air and $\mathrm{N}_{2}$, provide insights concerning the temperature threshold to initiate $\mathrm{SiN}_{\mathrm{x}}$ etching, the accompanying $\mathrm{Pb}$ formation, and hence the extent of $\mathrm{Ag}-\mathrm{Pb}$ alloying during contact firing.

As shown in Fig. 1b, which plots the ratio of $\mathrm{Pb}(111)$ integrated intensity to that of $\mathrm{Ag}(111)$, varying amounts of $\mathrm{Pb}$ form depending on both the maximum temperature and the firing atmosphere. $\mathrm{Pb}$ is not detected upon heating to $500{ }^{\circ} \mathrm{C}$, whereas heating to $600^{\circ} \mathrm{C}$ induces measurable $\mathrm{Pb}$ in both air and $\mathrm{N}_{2}$. Trend-lines show the amount of $\mathrm{Pb}$ increasing progressively with maximum firing temperature. Heating in $\mathrm{N}_{2}$ promotes $\mathrm{Pb}$ formation significantly compared with firing in air. Analogous behavior is observed in experiments with $\mathrm{Ag} / \mathrm{frit} / \mathrm{c}-\mathrm{Si}$, wherein $\mathrm{PbO}$ oxidizes c-Si by:

$$
2 \mathrm{PbO}+\mathrm{Si} \rightarrow 2 \mathrm{~Pb}+\mathrm{SiO}_{2}
$$

Enhanced $\mathrm{Pb}$ formation in $\mathrm{N}_{2}$ is explained by irreversible $\mathrm{PbO}$ reduction. In air, when $\mathrm{Pb}$ forms by reaction 1 , it tends to react with $\mathrm{O}_{2}$, or $\mathrm{Ag}_{2} \mathrm{O}$ in the frit if present, and oxidize back to $\mathrm{PbO}$ by:

$$
\mathrm{Pb}+\frac{1}{2} \mathrm{O}_{2} \rightarrow \mathrm{PbO}
$$

or:

$$
\mathrm{Ag}_{2} \mathrm{O}+\mathrm{Pb} \rightarrow 2 \mathrm{Ag}+\mathrm{PbO}
$$

respectively. Thus, it seems regeneration of $\mathrm{PbO}$ by reactions 6 and 7 allows complete $\mathrm{SiN}_{\mathrm{x}}$ etching despite a very small loading of $\mathrm{PbO}$ in the $\mathrm{Ag}$ paste (about $2 \mathrm{wt} . \%$ ), as these reactions perpetuate the burn-through process.

Burn-through reaction sequence revealed. Figure 2 shows diffraction patterns obtained from an $\mathrm{Ag} /$ frit// $\mathrm{SiN}_{\mathrm{x}} / \mathrm{Si}$ mixture at different stages of firing. The $\mathrm{Si}$ diffraction decreases during heating between 550 and $750^{\circ} \mathrm{C}$, and does not recover upon cooling. This suggests oxidation of c-Si by $\mathrm{Ag}_{2} \mathrm{O}$ (reaction 4) and/or $\mathrm{PbO}$ (reaction 5). The $\mathrm{Ag}$ peaks initially narrow during
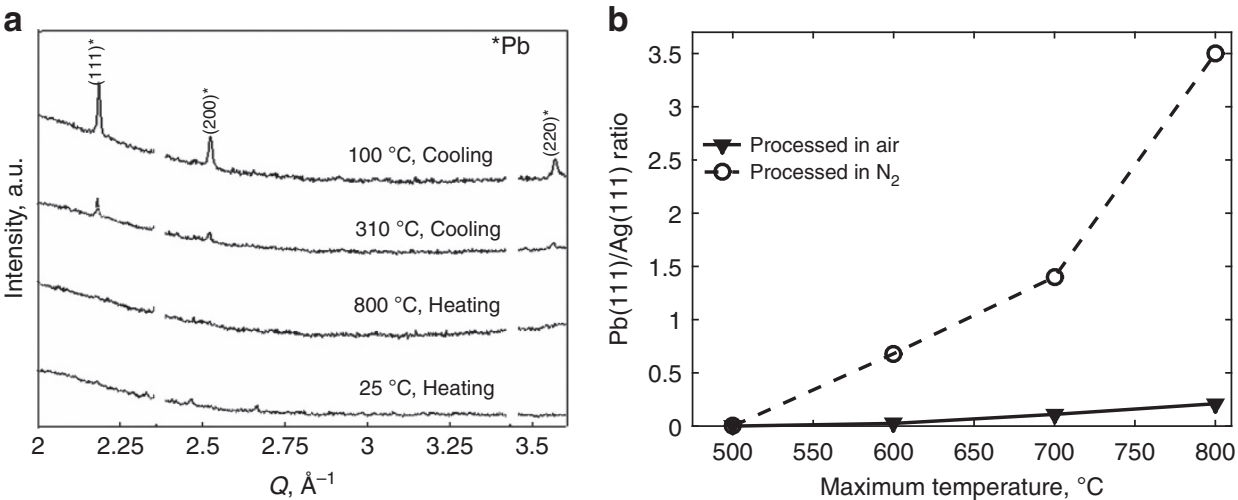

Figure 1 | Lead formation dependence on firing temperature and atmosphere. (a) XRD patterns measured from frit/SiN $\mathrm{N}_{x}$ during firing and cooling in air and (b) integrated $\mathrm{Pb}(111)$ diffraction intensity normalized by $\mathrm{Ag}(111)$ intensity observed upon firing $\mathrm{Ag} / \mathrm{frit}_{\mathrm{S}} \mathrm{SiN}_{\mathrm{x}}$ mixtures to varying temperatures in air and $\mathrm{N}_{2}$.

a

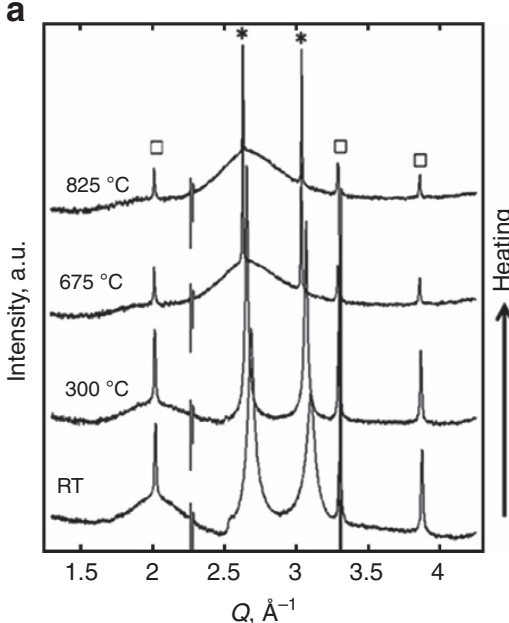

b

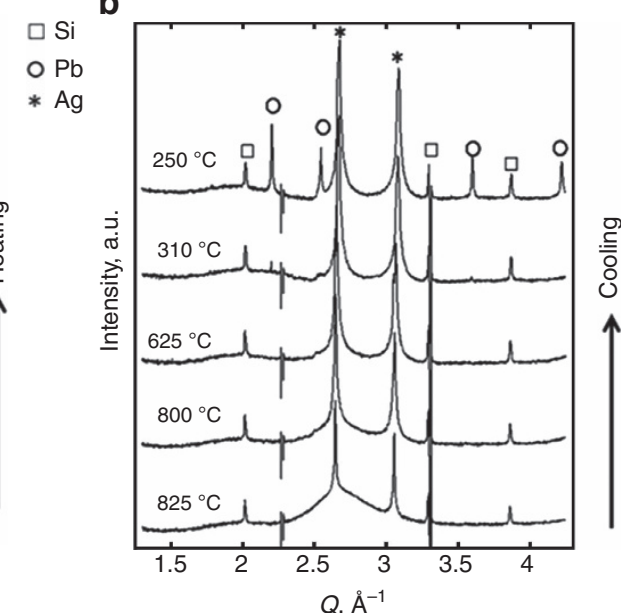

Figure 2 | In situ diffraction measured from $\mathbf{A g} /$ frit $/ \mathbf{S i N}_{\mathbf{x}} / \mathbf{S i}$ during firing. (a) XRD profiles obtained during heating to a max temperature of $825^{\circ} \mathrm{C}$ at $50^{\circ} \mathrm{C} \mathrm{s}^{-1}$ and (b) cooling in air. Squares, circles, and stars indicate $\mathrm{Si}, \mathrm{Pb}$ and $\mathrm{Ag}$ peaks, respectively. Note the changes in diffuse scattering from amorphous phases, near $Q=2 \AA^{-1}$ (attributed to glass frit) at low temperatures, and near $Q=2 . \AA^{-1}$ (attributed to molten metal) at $\sim 675-825^{\circ} \mathrm{C}$. 

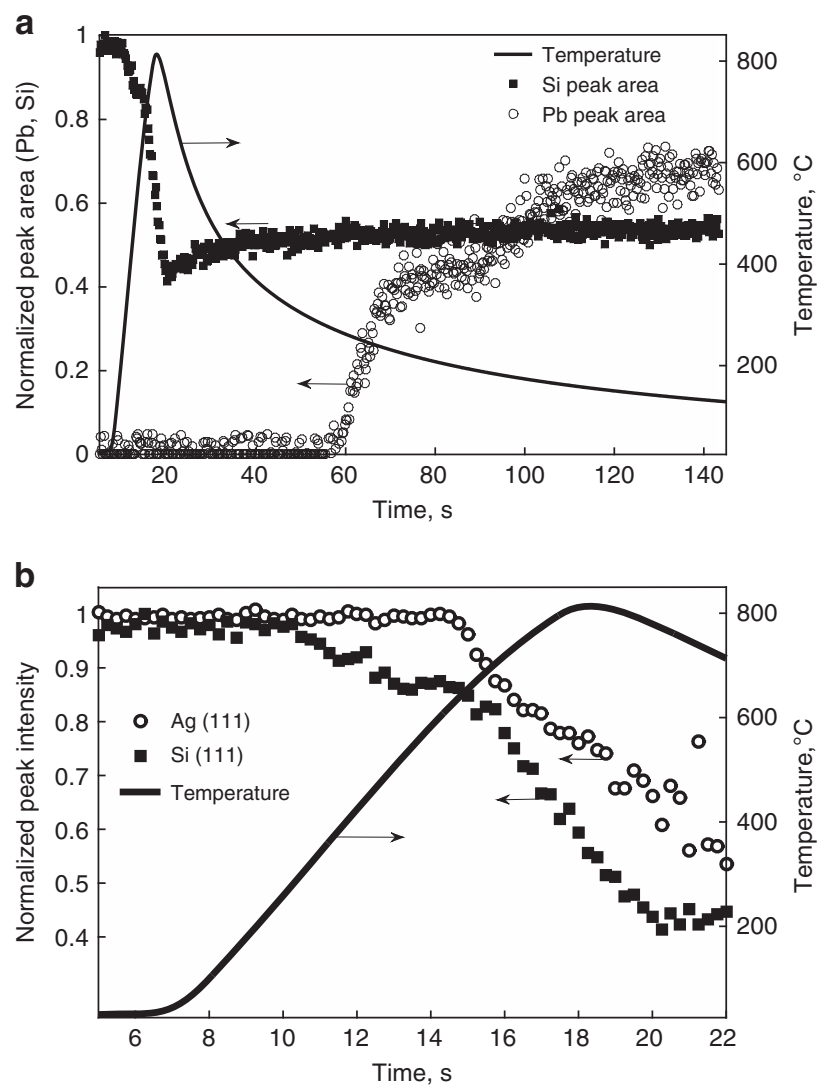

Figure 3 | In situ diffraction from a model frit system during firing in air. (a) Temperature profile versus time (solid line) and corresponding variation in $\mathrm{Si}$ and $\mathrm{Pb}$ diffraction intensity during temperature ramping and cooling. (b) $\mathrm{Si}$ and $\mathrm{Ag}$ peak-area observed during firing, along with the temperature ramp profile (solid line).

temperature ramping as a consequence of $\mathrm{Ag}$ grain growth by sintering and ripening. Then on further heating to temperatures above $650{ }^{\circ} \mathrm{C}$ the $\mathrm{Ag}$ peak intensity diminishes, and a diffuse peak emerges near the Ag (111) peak (that is, at $Q \cong 2.7 \AA^{-1}$ ). The emerging diffuse peak is attributed to scattering from an amorphous phase, such as liquid metal (possibly $\mathrm{Pb}$ or $\mathrm{Ag}-\mathrm{Pb}$ alloy), which is not present at room temperature and becomes most intense at the max temperature $\left(825^{\circ} \mathrm{C}\right)$ where the $\mathrm{Ag}$ peak intensity is a minimum. On cooling, the diffuse peak disappears while the Ag peaks gain intensity and broaden. Most likely, Ag peak broadening reflects contributions from newly formed Ag nanocrystals that precipitate within the glass during cooling. $\mathrm{Pb}$ peaks appear below $327^{\circ} \mathrm{C}$.

Loss of Ag diffraction intensity during temperature ramping most likely follows from one of two possible mechanisms: $\mathrm{Pb}$ formed by redox reaction with $\mathrm{SiN}_{\mathrm{x}}$ alloys and melts $\mathrm{Ag}$, or $\mathrm{Ag}$ oxidizes and dissolves into the molten frit by reaction 3 . In fact, the present study finds that both mechanisms occur, though with different onset temperatures. Examining the intensity trends versus time and temperature allows decoupling of the competing mechanisms. Figure 3 shows the corresponding temperature profile versus time along with $\mathrm{Ag}, \mathrm{Si}$ and $\mathrm{Pb}$ integrated intensities. The Si diffraction intensity begins to decrease at about $10 \mathrm{~s}$ $\left(500^{\circ} \mathrm{C}\right)$. Then, the Ag peak intensity begins to diminish $5 \mathrm{~s}$ later, at about $14 \mathrm{~s}\left(650^{\circ} \mathrm{C}\right)$. As the Ag signal begins to drop, the rate of $\mathrm{Si}$ signal loss accelerates markedly. Loss of Si signal results from $\mathrm{Si}$ oxidation by either $\mathrm{PbO}$ or $\mathrm{Ag}_{2} \mathrm{O}$ in the frit. $\mathrm{Ag}$ dissolution into the molten frit by reaction 3 must occur before etching by $\mathrm{Ag}_{2} \mathrm{O}$ (reaction 4). Since the Si signal decreases before the onset of $\mathrm{Ag}$

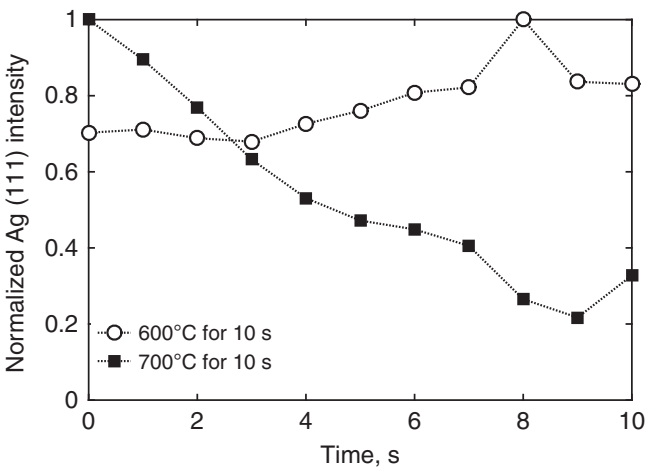

Figure 4 | In situ measurement of Ag diffraction during isothermal heating. $\mathrm{Ag}(111)$ diffraction intensity as function of time during heating of $\mathrm{Ag} /$ frit $\left(5 \mathrm{wt} . \% \mathrm{Ag}\right.$ ) in air suggests $\mathrm{Ag}$ dissolution into the frit at $700^{\circ} \mathrm{C}$, but not at $600^{\circ} \mathrm{C}$.
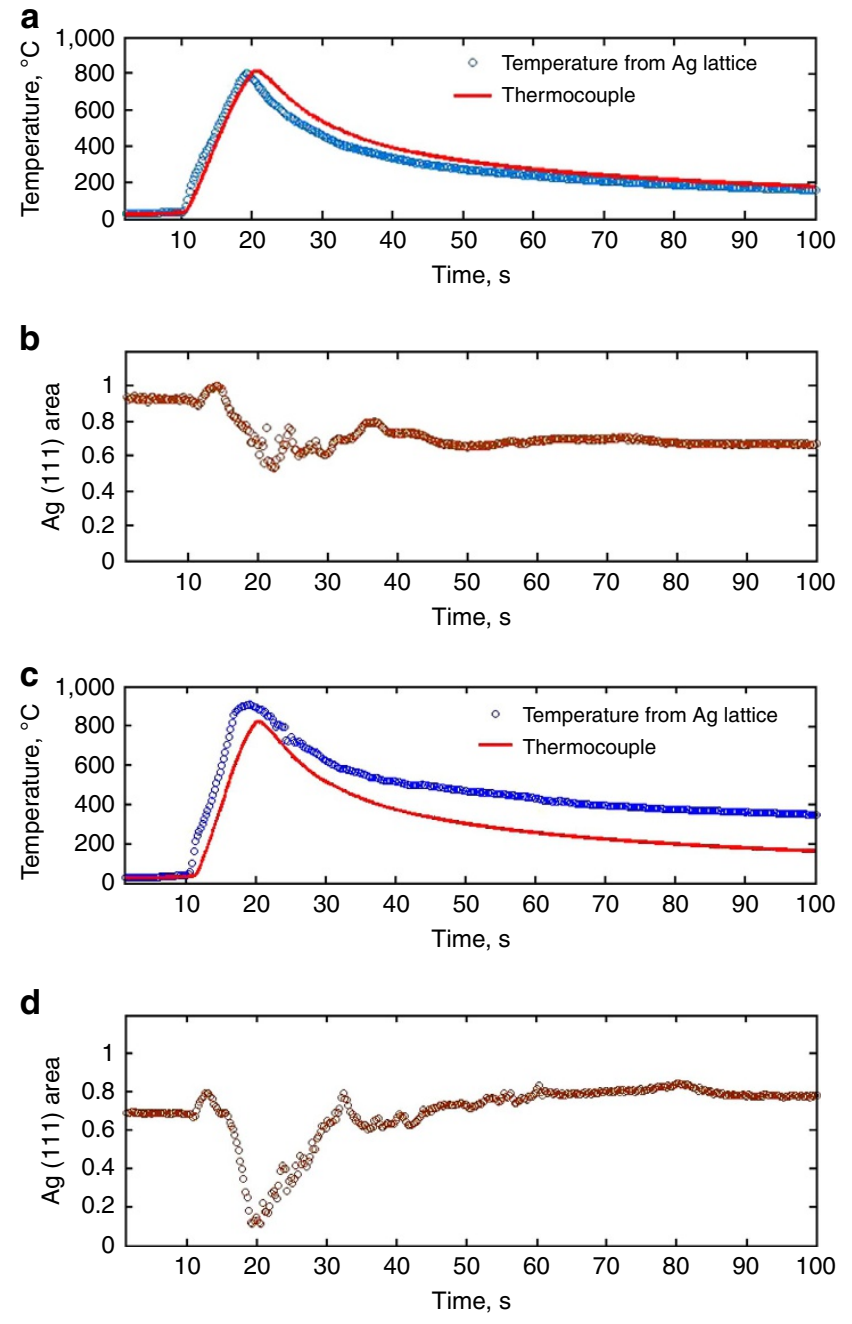

Figure 5 | Temperature profiles and Ag(111) diffraction measured from $\mathrm{Ag} /$ frit/ $\mathrm{SiN}_{\mathrm{x}} / \mathrm{Si}$ during firing $\left(100^{\circ} \mathrm{Cs}^{-1}\right)$ and cooling in air and $\mathbf{N}_{2}$. $(\mathbf{a}, \mathbf{c})$ shows the temperature measured by thermocouple (red lines) versus calculated based on the $\mathrm{Ag}$ peak position (blue lines), and (b,d) shows the $\mathrm{Ag}$ diffraction intensity dependence on time. $(\mathbf{a}, \mathbf{b})$ corresponds to firing in air, while $(\mathbf{c}, \mathbf{d})$ is in $\mathrm{N}_{2}$.

intensity loss, the low temperature oxidation $\left(<650^{\circ} \mathrm{C}\right)$ must be dominated by reaction with $\mathrm{PbO}$ in the frit (that is, by reaction 1). The observation of $\mathrm{Pb}$ diffraction upon cooling 
below $320^{\circ} \mathrm{C}$ supports this interpretation, as this confirms formation of $\mathrm{Pb}$.

Excellent agreement between the onset of Ag intensity decline and increased rate of $\mathrm{Si}$ oxidation at $15 \mathrm{~s}\left(650^{\circ} \mathrm{C}\right)$ suggests a change in the dominant oxidation reaction during temperature ramping - most likely the onset of $\mathrm{Si}$ etching by $\mathrm{Ag}_{2} \mathrm{O}$ (reaction 4). Indeed, with $\mathrm{Ag}$ being the most noble metal in the system, $\mathrm{Si}$ oxidation by $\mathrm{Ag}_{2} \mathrm{O}$, if present, should dominate given its thermodynamic favorability compared to reaction 1 (ref. 4).

Involvement of $\mathrm{Ag}$ in $\mathrm{SiN}_{\mathbf{x}}$ burn-through unlikely. Examining the nature of $\mathrm{Ag}$ dissolution into $\mathrm{PbO}$-based frit under varying temperature conditions negates the possibility of $\mathrm{Ag}$ participation in $\mathrm{SiN}_{\mathrm{x}}$ removal during the early stages of contact firing. To test this, $\mathrm{Ag} /$ frit mixtures (5 wt.\% Ag) were isothermally annealed at 600 and $700{ }^{\circ} \mathrm{C}$ for $10 \mathrm{~s}$. As shown in Fig. 4, annealing at $600^{\circ} \mathrm{C}$

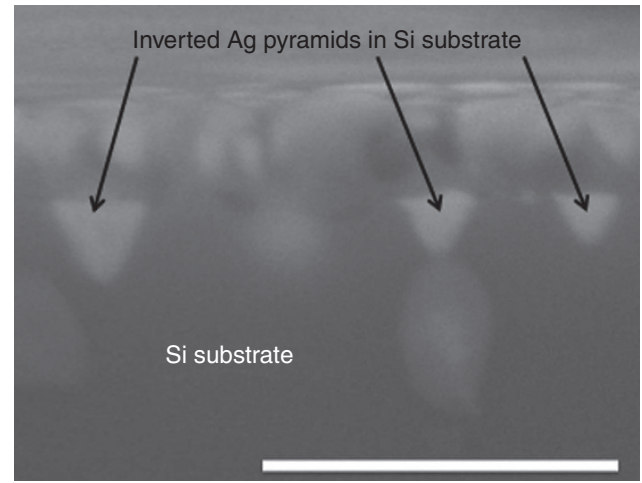

Figure 6 | Cross section SEM showing Ag pyramids in a fired test sample. SEM image at $\times 100,000$ magnification where the scale bar is $1 \mu \mathrm{m}$, shows a cross-section of an $\mathrm{Ag} / \mathrm{frit} / \mathrm{SiN}_{\mathrm{x}}$ sample fired to $800^{\circ} \mathrm{C}$ at $100^{\circ} \mathrm{Cs}^{-1}$ and reveals formation of inverted $\mathrm{Ag}$ pyramids penetrating the surface of the c-Si substrate.

a

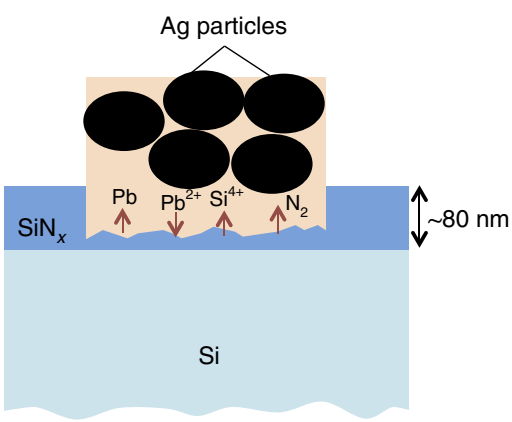

C

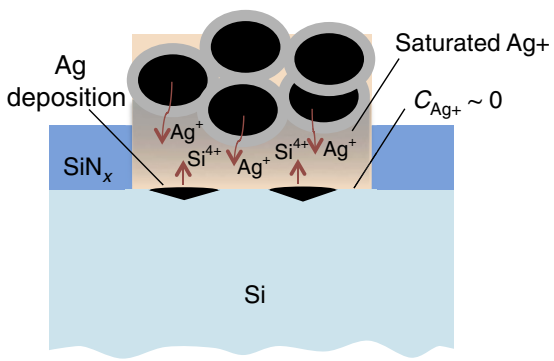

induces only a modest increase in $\mathrm{Ag}(111)$ intensity, probably due to grain growth. On the other hand, at $700{ }^{\circ} \mathrm{C}$, the $\mathrm{Ag}$ intensity decreases and only $30 \%$ of the initial intensity remains after $10 \mathrm{~s}$. The loss of Ag diffraction intensity implies about $70 \% \mathrm{Ag}$ dissolution into the frit by reaction 3. Therefore, Ag dissolution into the frit must occur with a temperature threshold between $600^{\circ} \mathrm{C}$ and $700^{\circ} \mathrm{C}$, and hence, oxidation of $\mathrm{SiN}_{\mathrm{x}}$ or Si (observed onset temperature is approximately $500^{\circ} \mathrm{C}$ ) below this temperature range cannot involve $\mathrm{Ag}^{+}$ions. The majority of $\mathrm{SiN}_{\mathrm{x}}$ oxidation during temperature ramping must therefore be attributed to redox reactions with $\mathrm{PbO}$.

Silver transport. Monitoring the Ag peak intensity during firing reveals the extent of $\mathrm{Ag}$ dissolution into the glass under varying conditions. Notably, the response of an $\mathrm{Ag} / \mathrm{frit} / \mathrm{SiN}_{\mathrm{x}} / \mathrm{Si}$ mixture strongly depends on whether firing occurs in air or $\mathrm{N}_{2}$ (Fig. 5). During heating, the $\mathrm{Ag}$ peaks initially become sharper as a consequence of grain growth, and the intensity increases slightly. Then, above $650^{\circ} \mathrm{C}$ (about $15 \mathrm{~s}$ ), the $\mathrm{Ag}$ intensity diminishes continuously with increasing temperature up to the maximum temperature of $810^{\circ} \mathrm{C}$ (about $20 \mathrm{~s}$ ). In both cases, air and $\mathrm{N}_{2}$ atmosphere, the Ag peak intensity recovers during cooling, albeit to a different extent. In air, as applies in solar cell manufacturing, the Ag signal intensity decreases to approximately $50 \%$ at maximum temperature, and then recovers to about $75 \%$ of the initial value on cooling. On the other hand, when firing in $\mathrm{N}_{2}$, the Ag signal intensity drops to just $10 \%$ of the initial value at the maximum temperature, and then recovers completely upon cooling.

The different behavior in air versus $\mathrm{N}_{2}$ reflects the different forms of Ag during firing, respectively. According to the equilibrium $\mathrm{Ag}-\mathrm{Pb}$ phase diagram, metallic $\mathrm{Pb}$ formed by redox reactions between $\mathrm{PbO}$ and $\mathrm{SiN}_{\mathrm{x}}$ readily forms a liquid alloy with $\mathrm{Ag}$ in this temperature range. As was previously shown, more $\mathrm{Pb}$ forms in $\mathrm{N}_{2}$ due to irreversible reduction of $\mathrm{PbO}$ (Fig. 1b). Hence more $\mathrm{Ag}-\mathrm{Pb}$ alloying occurs in $\mathrm{N}_{2}$, which is almost entirely

b
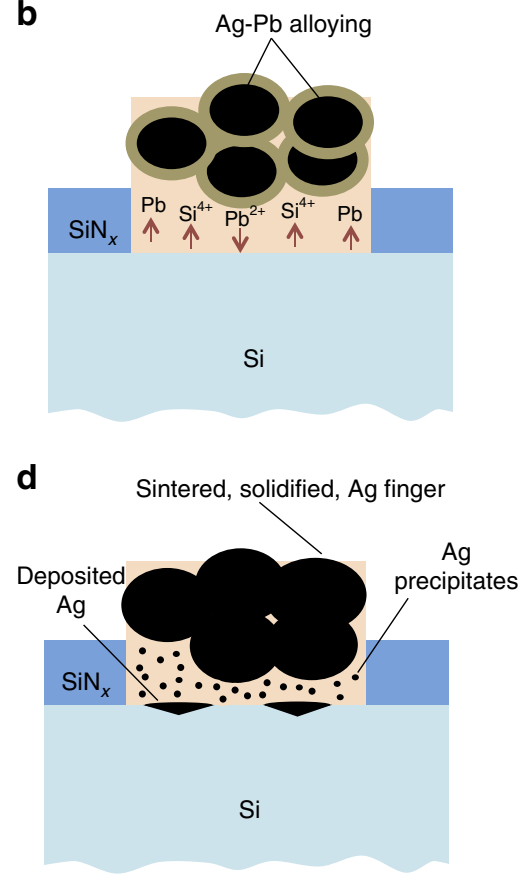

Figure 7 | Illustrations showing stages of contact formation during firing. (a) $\mathrm{SiN}_{\mathrm{x}}$ etching by $\mathrm{PbO}$ in the frit, (b) $\mathrm{Ag}-\mathrm{Pb}$ alloying, (c) $\mathrm{Ag}+$ transport through molten frit and deposition at the $\mathrm{Si}$ surface, and (d) resulting fired-contact morphology, with inclusion of small $\mathrm{Ag}$ precipitates within the glass intermediate layer. 
reversible due to low miscibility of $\mathrm{Ag}$ and $\mathrm{Pb}$ solid phases at lower temperatures. On the other hand, Fig. 4 showed that $\mathrm{Ag}$ dissolves readily into the glass in the presence of $\mathrm{O}_{2}$ above $650^{\circ} \mathrm{C}$. Thus, in the case of firing in air, the dip in Ag signal reflects both $\mathrm{Ag}-\mathrm{Pb}$ alloying and $\mathrm{Ag}$ dissolution, whereas only the former occurs in $\mathrm{N}_{2}$. In air, some of the $\mathrm{Ag}$ signal recovers as $\mathrm{Ag}$ nanocrystals precipitate within the glass upon cooling as a consequence of the temperature-dependent solubility. However, weak scattering from nanocrystals having a diameter below $2 \mathrm{~nm}$, as are commonly seen in cross-sections of fired contacts ${ }^{11-14}$, and Ag remaining bound as $\mathrm{Ag}^{+}$within the glass, are both consistent with lower Ag signal detected after firing in air.

Before considering implications of these results on screenprinted solar cell contacts, it is important to show that the model systems used in the present work behave representatively. Figure 6 shows a cross-section SEM of our model frit system with inverted Ag pyramids penetrating the surface of the c-Si substrate beneath the $\mathrm{Ag} / \mathrm{frit} / \mathrm{SiN}_{\mathrm{x}}$ mixture after firing. The $\mathrm{Ag}$ pyramid formation observed here is analogous to that observed in numerous prior studies on fired Ag contacts $3,7,13,15,16$. Therefore, our frit, powder mixtures and firing conditions clearly mimic the screen-printed contact firing process. Interestingly, in this case, the mixture contained a larger proportion of frit (1:1 frit/ $\mathrm{Ag})$ compared with common Ag pastes used in solar cell contacts (typically lower than 0.1:1), which seems to have induced a larger characteristic Ag pyramid size compared with most other studies.

\section{Discussion}

A complete picture of the contact formation process, consistent with all previous findings and informed by the present in situ results, emerges as follows: during firing, above $500^{\circ} \mathrm{C}$, the frit melts and wets the $\mathrm{Ag} / \mathrm{SiN}_{\mathrm{x}}$ interface. Between 500 and $650^{\circ} \mathrm{C}$, $\mathrm{PbO}$ in the frit reacts with and penetrates the $\mathrm{SiN}_{\mathrm{x}}$ anti-reflective layer by reaction 1 , as shown in Fig. $7 \mathrm{a}$. Pb formed during the burn-through process alloys with and assists in liquid-phase assisted sintering of $\mathrm{Ag}$ (Fig. $7 \mathrm{~b}$ ). Above $650^{\circ} \mathrm{C}, \mathrm{Ag}$ dissolves into the frit and diffuses towards the emitter surface. In the vicinity of the $\mathrm{Si}$ emitter surface, $\mathrm{Ag}$ ions are consumed by redox reaction 4 , which oxidizes $\mathrm{Si}$ to $\mathrm{SiO}_{2}$ and deposits metallic $\mathrm{Ag}$ on the emitter surface (Fig. $7 \mathrm{c}$ ). $\mathrm{SiO}_{2}$ formed by reaction 4 is incorporated into the molten frit. On cooling, the solubility of $\mathrm{Ag}$ in the melt decreases and nanocrystals precipitate from within the glass matrix. Kinetic constraints limit grain growth during fast cooling, resulting in a high density of distributed nanocrystals within the glass intermediate layer (Fig. 7d).

In summary, Ohmic contacts with low resistivity result when Ag crystals form within a thin glass intermediate layer and on the emitter surface; thus, in general, it would seem optimal contacts result with adequate heating to achieve complete $\mathrm{SiN}_{\mathrm{x}}$ opening and abundant Ag precipitation within the glass. At the same time, over-firing must be avoided both to prevent excessive Ag deposition onto the emitter - Ag spikes - which can shunt the $p n$-junction in extreme cases, and to minimize $\mathrm{SiO}_{2}$ generation, which increases the thickness of the glass layer and diminishes carrier tunneling.

In the larger effort to replace costly $\mathrm{Ag}$ and toxic $\mathrm{Pb}$ in the solar cell manufacturing sector, the present study offers several insights. To replace Ag with an alternative, low-resistivity metal, assuming suitable work-function alignment for contacting $\mathrm{Si}$, analogous use will require the metal have variable solubility in a frit system within a comparable temperature range (below $800^{\circ} \mathrm{C}$ ). The $\mathrm{PbO}$-based frit may be replaced by a frit system containing another metal-oxide that alloys with the primary contact metal upon metal-oxide reduction and provides a low glass transition temperature. This is a necessary condition to achieve wetting and adhesion at the contact interface. The frit must contain a reactive species with a negative redox potential in relation to $\mathrm{SiN}_{\mathrm{x}}$, and preferably to both $\mathrm{SiN}_{\mathrm{x}}$ and Si. Ultimately, metal solubility and transport kinetics enabling nanocrystal precipitation within the glass upon cooling, which allows carrier tunneling (that is, ohmic contact formation), depends strongly on the frit composition. Thus, the metal and accompanying frit used in the paste must be developed in tandem.

\section{Methods}

Model system. Ag, frit, $\mathrm{SiN}_{\mathrm{x}}$ and c-Si model systems in this study have been characterized as powder mixtures. Our model, controlled PbO-based frit was synthesized following ref. 15 by quenching a molten mixture of $\mathrm{PbO}(60 \mathrm{~mol} \%)$, $\mathrm{SiO}_{2}(30 \mathrm{~mol} \%)$ and $\mathrm{B}_{2} \mathrm{O}_{3}(10 \mathrm{~mol} \%)$, and then milling to form a powder. $\mathrm{Ag}$ nanocrystals and $\mathrm{SiN}_{\mathrm{x}}$ powder was purchased from Sigma-Aldrich, and c-Si nanocrystals were from Nanostructured and Amorphous Materials, Inc. Samples of varying composition were mixed to desired proportions in dry form, and then deposited onto $20 \times 20 \mathrm{~mm}$ Si wafer substrates using isopropyl alcohol as a dispersing agent. Multiple samples were characterized for each test condition to ensure the reliability of the data.

Measurement and heating. Our model systems were fired at heating rates around $100^{\circ} \mathrm{C} \mathrm{s}^{-1}$ and characterized by XRD in real-time using a synchrotron-mounted, RTP apparatus, equipped with a Pilatus, Dectris $300 \mathrm{~K}$ area detector, with $250 \mathrm{~ms}$ integration time ( $4 \mathrm{~Hz}$ sampling frequency). Specifics of the in situ XRD/RTP apparatus can be found elsewhere ${ }^{18}$. Briefly, the in situ RTP chamber was gold-coated aluminium enclosure with four high-power quartz-tungsten-halide lamps $(750 \mathrm{~W}$ each). The chamber is sealed and plumbed to allow atmosphere control. Al coated Kapton windows were used to allow high X-ray transmission while containing heat during thermal processing. The RTP chamber body was water cooled by means of a chiller. Firing under $\mathrm{N}_{2}$ atmosphere was accomplished by purging the RTP chamber for $5 \mathrm{~min}$ prior to heating. In situ temperature measurements were obtained using a thermocouple, and cross-referenced based on calculations using the Ag diffraction signal (that is, the temperature dependence of the Ag lattice). This method provides a high level of accuracy in temperature measurement.

Data analysis. Analysis of in situ XRD datasets was accomplished by fitting peaks with Pearson VII functions. The integrated area of the diffraction peak for a given phase corresponds directly with its abundance, which allowed extraction of phase-evolution trends versus time for the individual species of interest.

Cross-section SEM was performed using an FEI Nova NanoSEM, with a working-distance of $4.4 \mathrm{~mm}$, accelerating potential of $10 \mathrm{kV}$ and $1.3 \mathrm{~mA}$ operating current.

\section{References}

1. Mertens, R. et al. Critical processing parameter optimization for screen printed semicrystalline silicon solar cells. Proc. 17th IEEE PVSC 1347-1351 (1984).

2. Schubert, G., Fischer, B. \& Fath, P. Formation and nature of Ag thick film front contacts on crystalline silicon solar cells. Proc. PV Eur. Rome 343, 343-346 (2002).

3. Schubert, G., Huster, F. \& Fath, P. Physical understanding of printed thick-film front contacts of crystalline Si solar cells-review of existing models and recnet developments. Sol. Energy Mater. Sol. Cells 90, 3399-3406 (2006).

4. Horteis, M., Gutberlet, T., Reller, A. \& Glunz, S. W. High-temperature contact formation on n-type silicon: basic reactions and contact model for seed-layer contacts. Adv. Funct. Mater. 20, 476-484 (2010).

5. Ueda, S., Kumagai, T. \& Yamaguchi, K. Thermodynamic study on the Ag-Pb-O system at $1273 \mathrm{~K}$. Mater. Trans. 46, 1861-1864 (2005).

6. Ueda, S., Kumagai, T. \& Yamaguchi, K. Activity coefficient of $\mathrm{AgO}_{0.5}$ in the $\mathrm{PbO}-\mathrm{SiO}_{2}$ melt at $1273 \mathrm{~K}$. Mater. Trans. 48, 1458-1462 (2007).

7. Hong, K. K. et al. Mechanism for the formation of Ag crystallites in the Ag thick-film contacts of crystalline Si solar cells. Sol. Energy Mater. Sol. Cells 93, 898-904 (2009).

8. Chung, B. M. et al. Influence of oxygen on Ag ionization in molten lead borosilicate glass during screen-printed Ag contact formation for Si solar cells. Electrochim. Acta 106, 333-341 (2013).

9. Prudenziati, M., Moro, L., Morten, B., Sirotti, F. \& Sardi, L. Ag-based thick-film front metallization of silicon solar cells. Act. Pass. Elect. Comp. 13, 133-150 (1989).

10. Ballif, C., Huljic, D. M., Willeke, G. \& Hessler-Wyser, A. Silver thick-film contacts on highly doped n-type silicon emitters: structural and electrical properties of the interface. Appl. Phys. Letts. 82, 1878-1880 (2003).

11. Hilali, M. M. et al. Understanding the formation and temperature dependence of thick-film Ag contacts on high-sheet-resistance Si emitters for solar cells. J. ECS 152, 742-749 (2005). 
12. Psych, D., Mette, A., Filipovic, A. \& Glunz, S. W. Comprehensive analysis of advanced solar cell contacts consisting of printed fine-line seed layers thickened by silver plating. Prog. Photovoltaics 17, 101-114 (2009).

13. Hong, K. K., Cho, S. B., Huh, J. Y., Park, H. J. \& Jeong, J. W. Role of PbO-based glass frit in Ag thick-film contact formation for crystalline Si solar cells. Met. Mater. Int. 15, 307-312 (2009).

14. Cho, S. B., Hong, K. K., Huh, J. Y., Park, H. J. \& Jeong, J. W. Role of the ambient oxygen on the silver thick-film contact formation for crystalline silicon solar cells. Curr. Appl. Phys. 10, 222-225 (2010).

15. Schubert, G. Thick Film Metallization of Crystalline Silicon Solar Cells (PhD thesis, University of Konstanz, 2006).

16. Horteis, M. Fine-Line Printed Contacts on Crystalline Silicon Solar Cells ( $\mathrm{PhD}$ thesis, University of Konstanz, 2009).

17. Sopori, B. et al. Fundamental mechanisms in the fire-through contact metallization of Si solar cells: a review. in 17th Workshop on Crystalline Silicon Solar Cells and Modules: Materials and Processes; Workshop Proceedings. No. NREL/BK-520-42056 (National Renewable Energy Laboratory (NREL), Golden, CO, 2007).

18. Ahmad, M. I. et al. Rapid thermal processing chamber for in-situ x-ray diffraction. Rev. Sci. Inst. 86 130902-1-130902-7 (2015).

\section{Acknowledgements}

This project is funded through the Bridging Research Interactions through collaborating the Development Grants in Energy (BRIDGE) program under the SunShot initiative of the Department of Energy (DE-EE0005951). Sample preparation and SEM analysis were performed at the National Renewable Energy Laboratory, which is operated under the prime contract no. DE-AC36-08GO28308. In situ characterization was performed at the Stanford Synchrotron Radiation Laboratory, a national user facility operated by Stanford
University on behalf of the US Department of Energy, Office of Basic Energy Sciences, under contract no. DE-AC02-76SF00515. We thank Bobby To at NREL for performing the SEM analysis, and Ron Marks and Bart Johnson at SSRL for assistance with beam line $7-2$.

\section{Author contributions}

J.D.F., M.I.A., V.L.P., M.F.A.M.v.H. and M.F.T. conceived and designed the experiments J.D.F. synthesized and prepared the samples. J.D.F., M.I.A., V.L.P., J.Y. and M.F.A.M.v.H conducted X-ray experiments. M.I.A., D.V.C. and J.Y. designed and built the RTP chamber with input from M.F.A.M.v.H. and P.A.P. M.I.A. and M.F.T. analyzed the diffraction data. All authors discussed the results and contributed to the manuscript.

\section{Additional information}

Competing financial interests: The authors declare no competing financial interests

Reprints and permission information is available online at http://npg.nature.com/ reprintsandpermissions/

How to cite this article: Fields, J. D. et al. The formation mechanism for printed silver-contacts for silicon solar cells. Nat. Commun. 7:11143 doi: 10.1038/ncomms11143 (2016)

\section{(c) (i)}

This work is licensed under a Creative Commons Attribution 4.0 International License. The images or other third party material in this article are included in the article's Creative Commons license, unless indicated otherwise in the credit line; if the material is not included under the Creative Commons license, users will need to obtain permission from the license holder to reproduce the material. To view a copy of this license, visit http://creativecommons.org/licenses/by/4.0/ 